University of Nebraska - Lincoln

DigitalCommons@University of Nebraska - Lincoln

Publications from USDA-ARS / UNL Faculty

U.S. Department of Agriculture: Agricultural

Research Service, Lincoln, Nebraska

6-14-2008

\title{
Soil Carbon Levels in Irrigated Western Corn Belt Rotations
}

Gary E. Varvel

University of Nebraska-Lincoln, gevarvel@windstream.net

Wallace Wilhelm

University of Nebraska-Lincoln, wwilhelm1@unl.edu

Follow this and additional works at: https://digitalcommons.unl.edu/usdaarsfacpub

Part of the Agricultural Science Commons

Varvel, Gary E. and Wilhelm, Wallace, "Soil Carbon Levels in Irrigated Western Corn Belt Rotations" (2008). Publications from USDA-ARS / UNL Faculty. 214.

https://digitalcommons.unl.edu/usdaarsfacpub/214

This Article is brought to you for free and open access by the U.S. Department of Agriculture: Agricultural Research Service, Lincoln, Nebraska at DigitalCommons@University of Nebraska - Lincoln. It has been accepted for inclusion in Publications from USDA-ARS / UNL Faculty by an authorized administrator of DigitalCommons@University of Nebraska - Lincoln. 


\title{
Soil Carbon Levels in Irrigated Western Corn Belt Rotations
}

\author{
G. E. Varvel* and W. W. Wilhelm
}

\begin{abstract}
Proposals promoting the use of massive amounts of crop residues and other lignocellulosic biomass for biofuel production have increased the need for evaluation of the sustainability of cropping practices and their effect on environment quality. Our objective was to evaluate the effects of crop rotation and $\mathrm{N}$ fertilizer management and their stover production characteristics on soil organic carbon (SOC) levels in a long-term high-yielding irrigated study in the western Corn Belt. An irrigated monoculture corn (Zea mays L.), monoculture soybean [Glycine max (L.) Merr.], and soybean-corn cropping systems study was initiated in 1991 on a uniform site in the Platte Valley near Shelton, NE. Soil samples were collected in 1991 before initiation of the study and in the spring of 2005 and analyzed for SOC. Significant differences in total SOC values were obtained between rotations and $\mathrm{N}$ rates at the 0 - to 7.5 - and 0 - to $15-\mathrm{cm}$ depths in 2005 and all total SOC values were equal to or greater than SOC values obtained in 1991. Residue production was greater than $6 \mathrm{Mg} \mathrm{ha}^{-1}$, a level that appears to be sufficient to maintain SOC levels, in all systems. Can residue amounts above this level be harvested sustainably for biofuel production in cropping systems similar to these? Though these results suggest that a portion of corn stover could be harvested without reducing SOC under the conditions of this investigation, the direct impact of stover removal remains to be evaluated.
\end{abstract}

$I^{2}$ NCREASING ENERGY DEMANDS, increasing prices, declining petroleum reserves, political instability in oil-rich areas of the world, all call for greater use of domestically produced fuels, and global warming concerns have intensified interest in biofuel production as a possible source. Various biofuel goals have been offered, and if achieved, will create a massive demand for lignocellulosic feedstock (Council for Agricultural Science and Technology, 2007). Recent reports, such as the Billion Ton Report (Perlack et al., 2005), conclude that with creation and adoption of new technology and production practices, U.S. agriculture and forest lands have the capacity to sustainably produce the immense amounts of lignocellulosic material needed to meet the $30 \times 30$ goal (Foust et al., 2007). One of the newest and least evaluated new production practices associated with biofuel production is widespread, intensive, recurring harvest of corn stover and other crop residues (i.e., aboveground, nongrain crop biomass).

Cropping system effects on soil properties are needed to provide information necessary to evaluate sustainability of production practices and their effect on environment quality. The pressure to identify appropriate parameters to evaluate the sus-

G.E. Varvel and W.W. Wilhelm, USDA-ARS and Dep. of Agron. and Hortic., Univ. of Nebraska, Lincoln, NE 68583. Joint contribution of USDA-ARS and the Nebraska Agric. Res. Division. Trade names and company names are included for the benefit of the reader and do not imply any endorsement or preferential treatment of the product by the authors, USDA-ARS, or the Agric. Res. Div. of the Univ. of Nebraska. Received 29 Nov. 2007. *Corresponding author (Gary.Varvel@ars.usda.gov).

Published in Agron. J. 100:1180-1184 (2008) doi:10.2134/agronj2007.0383 Copyright (C) 2008 by the American Society of Agronomy, 677 South Segoe Road, Madison, WI 53711. All rights reserved. No part of this periodical may be reproduced or transmitted in any form or by any means, electronic or mechanical, including photocopying, recording, or any information storage and retrieval system, without permission in writing from the publisher. tainability of soil management practices is becoming critical given the desire to increase our energy security and reduce greenhouse gas production through increasing use of renewable fuels. Corn stover is presented as a major feedstock available for biofuel production that could supply as much as $25 \%$ of the estimated feedstock needed in 2030 to meet the goals of the $30 \times 30$ plan (Foust et al., 2007), and is considered essentially a low-cost waste material in their report. The Billion Ton report assumes the major use of corn stover (and other crop residues) in current crop management systems is to manage erosion and any residue above that needed for erosion control is sustainably available for removal and use in biofuel production. The need to replenish SOC is acknowledged in the Billion Ton report, but not incorporated into the estimates of sustainably harvestable crop residue. This definition of sustainability (i.e., retaining sufficient stover in the field to control erosion) has been questioned (Wilhelm et al., 2004; Lal, 2004; Johnson et al., 2007). Authors of the latter reports have asserted that maintaining SOC or soil quality may require retention of more stover than the amount needed to control erosion. Shukla et al. (2006) recently stated that $\mathrm{SOC}$ is the best single measure of soil quality. Johnson et al. (2006) reported that the amount of crop residue needed to maintain SOC can range from 5.25 to $12.50 \mathrm{Mg} \mathrm{ha}^{-1}$ depending on cropping system and tillage practices. Wilhelm et al. (2007) showed that these values exceed the crop residue required to control erosion by as much as $10 \times$ in typical Corn Belt soils.

Opportunities to make measurements of the amount of crop residue needed to maintain SOC in the Corn Belt are somewhat limited since few long-term studies exist (Johnson et al., 2006). Given the lack of directly applicable studies or data on crop residue return on SOC, our specific objective was to evaluate the effects of crop rotation and $\mathrm{N}$ fertilizer management (practices that affect crop residue production) on SOC levels in an irrigated, high-yield long-term study in the western Corn Belt.

Abbreviations: SOC, soil organic carbon. 


\section{MATERIALS AND METHODS}

An irrigated monoculture corn, monoculture soybean, and soybean-corn rotation study was initiated in 1991 on a uniform site in the Platte Valley near Shelton, NE, on a Hord silt loam (fine-silty, mixed, superactive, mesic, Cumulic Haplustoll). Before initiation of the study, the site had been in a monoculture corn production system for more than $10 \mathrm{yr}$. At the beginning of the study, corn stalks from the previous growing season were shredded and the entire area was disked twice before planting. Similarly, each year following, corn stalks in both continuous corn and soybean-corn cropping systems were shredded and the entire area, including that which had been in soybean, was disked twice before planting.

A split-split-split plot treatment design within a randomized complete block experiment with four replications was used. Cropping systems were assigned as the main plots, corn hybrids as the subplots, and $\mathrm{N}$ fertilizer regimes as the sub-subplots. All phases of the monoculture corn and soybean-corn systems appeared each year starting with the 1991 growing season. Four Pioneer brand corn hybrids $(3162,3379,3394$, and 3417) differing in yield potential and maturity were selected and used in both the monoculture and rotation systems from 1991 through 2000. In subsequent years, new corn hybrids with similar growth characteristics and maturity groups were selected to replace the four original hybrids. For 2001 and 2002 they were Pioneer brand hybrids 32R42, 33B50, 33G26, and 33P66 and for 2003 and 2004 they were Pioneer brand hybrids 31N27, 33B50, 33V15, and 33P66. All corn hybrids were planted between late April and mid-May in 8-row (91-cm row spacing) by 15.2 -m-long plots at approximately 74,000 seeds ha ${ }^{-1}$. Soybean in the continuous soybean and soybean-corn cropping systems were planted in early May to mid-May. Several different soybean varieties were used for the duration of the study, but all were from a similar maturity group. Except for $\mathrm{N}$ fertilizer application rates (described below), both corn and soybean were produced using production practices typical to the area.

Nitrogen fertilizer as $\mathrm{NH}_{4} \mathrm{NO}_{3}$ was broadcast and immediately incorporated with 6- to 7-mm sprinkler irrigation in early June when corn was at approximately V2 or V3 growth stages (Ritchie et al., 1986). Six fertilizer $\mathrm{N}$ regimes including five fixed $\mathrm{N}$ fertilizer rates $\left(0,50,100,150\right.$, and $\left.200 \mathrm{~kg} \mathrm{Nha}^{-1}\right)$ and one as needed rate (Varvel et al., 1997) were used on both crops. Only data from the fixed $\mathrm{N}$ rate treatments were used for this analysis. Irrigation was provided with a linear-drive sprinkler system.

Aboveground dry matter samples from an area $0.91 \mathrm{~m}$ wide by $3.04 \mathrm{~m}$ long from all corn plots were collected every year soon after physiological maturity, in September or early October. Ears were removed, dried, and weighed. Stalks were cut at ground level, chopped, weighed, and a subsample was taken for gravimetric moisture determinations for calculation of stover dry matter production. Grain yields were determined from the dry mass of grain shelled from ears collected in the 3.04-m length of row. After shelling, cob weights were added to the calculated stover weight to obtain total nongrain dry matter (stover) production.

Aboveground dry matter samples were also collected from soybean plots in both continuous soybean and soybean-corn cropping systems from 1991 through 1999. Not all plots were sampled in all years. Soybeans were cut at ground level using a
Suzue binder from an area $0.56 \mathrm{~m}$ wide by $3.04 \mathrm{~m}$ long, soon after physiological maturity. The entire sample was weighed, dried, and weighed again for gravimetric moisture determinations for calculation of total dry matter production. The entire sample was then threshed with a stationary thresher to determine seed yield. Soybean stover yield was determined by subtracting seed yield from total dry matter yield.

Before initiation of the study, three composite soil samples were taken from the entire study area (east to west) approximately every $300 \mathrm{ft}$. Several cores (5 to 10) at each of the three locations were taken to a depth of $90 \mathrm{~cm}$ in 0 - to 15-, 15- to 30-, and 30 - to $90-\mathrm{cm}$ depth increments and composited by depth. Several analyses were run to characterize the site, but soil organic matter was determined only for the 0 - to 15 -cm depth. Soil organic matter content for these samples was determined by the Walkley Black method as described by Combs and Nathan (1998) and then converted to SOC as also described by Combs and Nathan (1998). These results were then used to compare to results from the 0 - to $15-\mathrm{cm}$ depth sampled in 2005.

Soil samples were taken in the spring of 2005 from all plots in the continuous corn and soybean-corn cropping systems and from 24 plots of the continuous soybean cropping system, 5 in each block that had received the fixed $\mathrm{N}$ fertilizer treatments as described above. Fifteen cores (1.8 cm diameter) were taken to a depth of $30 \mathrm{~cm}$ in 0 - to 7.5-, 7.5- to 15-, and 15- to $30-\mathrm{cm}$ depth increments from each plot and composited by depth.

All samples from 2005 were air-dried, ground to pass a 2-mm screen, and then analyzed for total $\mathrm{C}$ using an automatic C analyzer, a Carlo Erba Model 1500 CNS Analyzer (Carlo Erba Strumentazione, Milan, Italy) interfaced with a continuous-flow mass spectrometer, a Tracer Mass Stable Isotope Spectrometer (Europa Scientific Limited, Crewe, England; Schepers et al., 1989). Total C equates to SOC as all soils were at a $\mathrm{pH}$ of 6.5 or lower. Soil bulk density was determined by using the volume and dry weights from the 15 sample cores from each subplot.

Data from the study were analyzed both within and across cropping systems using regression analyses. All statistical analyses were performed using PC Version 9.1 of the Statistical Analyses System for Windows (SAS Institute, 2003).

\section{RESULTS AND DISCUSSION}

Initial analyses of both the SOC and bulk density results were done within continuous corn and soybean-corn cropping systems using the appropriate model for the split-split plot analyses. This approach was taken to determine if differences in SOC or bulk density were obtained between hybrids (varieties) within these two systems separately. No significant differences in either SOC or bulk density were obtained between hybrids, hybrid $\times$ rotation, hybrid $\times \mathrm{N}$ rate, or hybrid $\times$ rotation $\times \mathrm{N}$ rate (analyses not shown). No differences in these measured soil variables were expected since grain and dry matter yields for all hybrids responded similarly to $\mathrm{N}$ fertilizer applications (Varvel and Wilhelm, 2003). Since there were no significant differences due to hybrid or its interaction with the other variables, we combined the results at similar $\mathrm{N}$ rates within each hybrid in both these systems. This approach allowed us to use a much simpler model where we could directly compare SOC and bulk 
Table I. Total organic soil C concentrations and bulk density $\left(P_{b}\right)$ values as affected by rotation and $\mathrm{N}$ rate at the 0 - to 7.5-, 7.5- to I5-, and I5- to 30-cm depths in 2005 at Shelton, NE.

\begin{tabular}{|c|c|c|c|c|c|c|c|}
\hline \multirow[b]{2}{*}{ Rotation $\dagger$} & \multirow[b]{2}{*}{$\mathbf{N}$ rate } & \multicolumn{3}{|c|}{ C } & \multicolumn{3}{|c|}{$P_{b}$} \\
\hline & & $0-7.5 \mathrm{~cm}$ & $7.5-15 \mathrm{~cm}$ & $15-30 \mathrm{~cm}$ & $0-7.5 \mathrm{~cm}$ & $7.5-15 \mathrm{~cm}$ & $15-30 \mathrm{~cm}$ \\
\hline & $\mathrm{kg} \mathrm{ha}^{-1}$ & & $-\mathrm{g} \mathrm{kg}^{-1}$ & & & $-\mathrm{g} \mathrm{cm}^{-3}$ & \\
\hline \multirow[t]{5}{*}{$\mathrm{CC}$} & 0 & 12.6 & 9.7 & 8.4 & 1.27 & 1.47 & 1.48 \\
\hline & 50 & 13.5 & 9.8 & 8.4 & 1.25 & 1.44 & 1.47 \\
\hline & 100 & 14.1 & 9.7 & 8.2 & 1.27 & 1.48 & 1.50 \\
\hline & 150 & 14.2 & 10.0 & 8.3 & 1.24 & 1.42 & 1.45 \\
\hline & 200 & 14.9 & 10.4 & 8.6 & 1.25 & 1.46 & 1.49 \\
\hline \multirow[t]{5}{*}{ CSB } & 0 & 12.0 & 9.9 & 8.6 & 1.18 & 1.38 & 1.43 \\
\hline & 50 & 12.8 & 10.7 & 9.4 & 1.14 & 1.33 & 1.41 \\
\hline & 100 & 11.9 & 9.7 & 8.4 & 1.23 & 1.40 & 1.45 \\
\hline & 150 & 11.8 & 9.9 & 8.4 & 1.17 & 1.34 & 1.43 \\
\hline & 200 & 12.2 & 10.2 & 8.4 & 1.19 & 1.38 & 1.46 \\
\hline \multirow[t]{5}{*}{$\mathrm{C} / \mathrm{SB}$} & 0 & 12.6 & 9.8 & 8.2 & 1.21 & 1.40 & 1.43 \\
\hline & 50 & 12.9 & 10.1 & 8.3 & 1.20 & 1.40 & 1.42 \\
\hline & 100 & 12.7 & 10.0 & 8.2 & 1.18 & 1.40 & 1.43 \\
\hline & 150 & 12.9 & 10.1 & 8.3 & 1.21 & 1.41 & 1.42 \\
\hline & 200 & 13.0 & 10.1 & 8.4 & 1.24 & 1.43 & 1.45 \\
\hline $\mathrm{CV}, \%$ & & 4.5 & 7.4 & 7.5 & 4.3 & 3.7 & 3.4 \\
\hline Source of variation & $\underline{d f}$ & \multicolumn{6}{|c|}{ Mean squares } \\
\hline Replication & 3 & $6.68 * * *$ & $11.49 * * *$ & $5.95 * * *$ & $0.017 * *$ & $0.022 * * *$ & $0.128^{* * * *}$ \\
\hline Rotation & 2 & $15.32 * * *$ & 0.12 & 0.82 & $0.029 * * *$ & $0.041 * * *$ & $0.014 * *$ \\
\hline $\mathrm{CC} \& \mathrm{CSB}$ vs. $\mathrm{C} / \mathrm{SB} \neq$ & I & 0.44 & 0.00 & 0.78 & 0.002 & 0.000 & 0.008 \\
\hline CSB vs. CC\&C/SB $\ddagger$ & i & $19.59 * * *$ & 0.17 & $1.55^{*}$ & $0.034 * *$ & $0.059 * * *$ & 0.006 \\
\hline $\mathrm{N}$ rate & 4 & $1.48 * *$ & 0.52 & 0.31 & 0.002 & 0.004 & 0.002 \\
\hline Linear $\ddagger$ & I & $3.87 * *$ & 0.50 & 0.06 & 0.001 & 0.001 & 0.002 \\
\hline Quadratic $\neq$ & I & 0.07 & 0.04 & 0.02 & 0.001 & 0.002 & 0.001 \\
\hline Rotation $\times \mathrm{N}$ rate & 8 & $1.10 * *$ & 0.26 & 0.27 & 0.003 & 0.001 & 0.001 \\
\hline Error & 42 & 0.34 & 0.55 & 0.40 & 0.003 & 0.003 & 0.002 \\
\hline
\end{tabular}

* Significant at the 0.05 probability level.

** Significant at the 0.01 probability level.

$* * *$ Significant at the 0.001 probability level.

$+C C=$ continuous corn, $\mathrm{CSB}=$ continuous soybean, $\mathrm{C} / \mathrm{SB}=$ corn-soybean.

$\ddagger$ Contrasts.

Table 2. Total SOC as affected by rotation and $\mathrm{N}$ rate at the 0 - to 7.5-, 7.5- to 15-, 15 to 30-, 0- to 15-, and 0- to 30-cm depths in 2005 at Shelton, NE.

\begin{tabular}{|c|c|c|c|c|c|c|}
\hline \multirow[b]{2}{*}{ Rotation $\dagger$} & \multirow[b]{2}{*}{$\mathbf{N}$ rate } & \multicolumn{5}{|c|}{ Total SOC } \\
\hline & & $0-7.5 \mathrm{~cm}$ & $7.5-15 \mathrm{~cm}$ & $15-30 \mathrm{~cm}$ & $0-15 \mathrm{~cm}$ & $0-30 \mathrm{~cm}$ \\
\hline & $\mathrm{kg} \mathrm{ha}^{-1}$ & & & $\mathrm{Mg} \mathrm{ha}^{-1}$ & & \\
\hline \multirow[t]{5}{*}{$\mathrm{CC}$} & 0 & 12.12 & 10.81 & 18.73 & 22.93 & 41.66 \\
\hline & 50 & 12.86 & 10.62 & 18.68 & 23.48 & 42.16 \\
\hline & 100 & 13.48 & 10.86 & 18.62 & 24.35 & 42.97 \\
\hline & 150 & 13.34 & 10.81 & 18.07 & 24.15 & 42.22 \\
\hline & 200 & 14.13 & 11.50 & 19.20 & 25.63 & 44.83 \\
\hline \multirow[t]{5}{*}{ CSB } & 0 & 10.69 & 10.29 & 18.77 & 20.98 & 39.75 \\
\hline & 50 & 11.10 & 10.76 & 20.25 & 21.86 & 42.11 \\
\hline & 100 & II.I4 & 10.31 & 18.56 & 21.45 & 40.01 \\
\hline & 150 & 10.43 & 10.02 & 18.34 & 20.46 & 38.79 \\
\hline & 200 & 10.93 & 10.64 & 18.66 & 21.58 & 40.24 \\
\hline \multirow[t]{5}{*}{$\mathrm{C} / \mathrm{SB}$} & 0 & 11.48 & 10.36 & 17.70 & 21.85 & 39.55 \\
\hline & 50 & 11.73 & 10.72 & 17.82 & 22.45 & 40.26 \\
\hline & 100 & 11.37 & 10.54 & I7.8| & 21.91 & 39.72 \\
\hline & 150 & II.84 & 10.70 & 17.82 & 22.54 & 40.36 \\
\hline & 200 & 12.30 & 10.90 & $|8.5|$ & 23.20 & 41.72 \\
\hline $\mathrm{CV}, \%$ & & 5.0 & 6.0 & 6.3 & 4.5 & 5.0 \\
\hline Source of variation & $\underline{\mathrm{df}}$ & & & Mean squares & & \\
\hline Replication & $\overline{3}$ & $3.92 * * *$ & $8.94 * * *$ & $59.05 * * *$ & $18.02 * * *$ & $129.70 * * *$ \\
\hline Rotation & 2 & $27.64 * * *$ & $1.32 *$ & $5.20 *$ & $41.00 * * *$ & $42.31 * * *$ \\
\hline CC\&CSB vs. C/SB $\ddagger$ & 1 & 1.05 & 0.00 & $9.75 *$ & 1.17 & 17.70* \\
\hline CSB vs. $C C \& C / S B \ddagger$ & I & $34.42 * *$ & $1.90 *$ & 5.12 & $52.48 * * *$ & $24.8 I^{*}$ \\
\hline $\mathrm{N}$ rate & 4 & $1.61 * *$ & 0.56 & 1.43 & $3.80 *$ & 7.76 \\
\hline Linear $\neq$ & 1 & $4.92 * * *$ & 0.89 & 0.00 & $9.99 * *$ & 9.60 \\
\hline Quadratic $\neq$ & I & 0.00 & 0.35 & 0.46 & 0.37 & 1.66 \\
\hline Rotation $\times \mathrm{N}$ rate & 8 & $0.76 *$ & 0.20 & 0.99 & 1.39 & 3.62 \\
\hline Error & 42 & 0.34 & 0.42 & 1.36 & 1.04 & 4.19 \\
\hline \multicolumn{7}{|c|}{ * Significant at the 0.05 probability level. } \\
\hline \multicolumn{7}{|c|}{ ** Significant at the 0.01 probability level. } \\
\hline \multicolumn{7}{|c|}{$* * *$ Significant at the 0.001 probability level. } \\
\hline \multicolumn{7}{|c|}{$\dagger C C=$ continuous corn, $C S B=$ continuous soybean, $C / S B=$ corn-soybean. } \\
\hline
\end{tabular}

density results between all three rotations and $\mathrm{N}$ rates. The results of this approach and these analyses are shown in Table 1. There were significant differences in SOC concentrations due to the main effects of rotation, $\mathrm{N}$ rate, and the rotation $\times \mathrm{N}$ rate interaction only in the 0 - to $7.5-\mathrm{cm}$ depth (Table 1). The significant rotation $\times \mathrm{N}$ rate interaction appeared to be due to increased SOC concentrations in both the continuous corn and soybean-corn systems with increasing $\mathrm{N}$ rate, but not in the continuous soybean system (Table 1). These results are similar to those obtained by many others throughout the United States and world as noted in a global analysis by West and Post (2002).

Soil bulk density results for samples taken in 2005 from the long-term irrigated cropping system study at Shelton, NE, are also shown in Table 1. There were significant differences in bulk density values due to the main effects of rotation at all three depths (Table 1). The $\mathrm{N}$ rate main effect and rotation $\times \mathrm{N}$ rate interaction did not affect bulk density values at any of the depths (Table 1). Bulk density values were significantly less in the continuous soybean vs. continuous corn and soybean-corn cropping systems at the 0 - to 7.5 -cm depth (1.18 vs. 1.26 and 1.20 $\mathrm{g} \mathrm{cm}^{-3}$ ) and 7.5 - to $15-\mathrm{cm}$ depth (1.36 vs. 1.45 and $1.40 \mathrm{~g} \mathrm{~cm}^{-3}$ ), respectively (Table 1). Karlen et al. (2006) also reported greater bulk density values in continuous corn than from soybean-corn systems in a soil quality study comparing crop rotation effects at three northern Corn Belt locations.

To better understand the effects of these cropping systems and $\mathrm{N}$ fertilizer treatments on SOC, total SOC values were calculated (using bulk density values) for each of the sampled depths ( 0 to $7.5,7.5$ to 15 , and 15 to $30 \mathrm{~cm}$ ) and then summed to examine the effects in the 0 to 15 - and 15- to 30-cm depths (Table 2). There were significant differences in SOC values due to the main effects of rotation at all depths, $\mathrm{N}$ rate at the 0 - to 7.5 - and 0 - to $15-\mathrm{cm}$ depths, and the rotation $\times \mathrm{N}$ rate interaction only in the 0 - to 7.5-cm depth (Table 2). The significant rotation $\times \mathrm{N}$ rate interaction in the 0 - to $7.5-\mathrm{cm}$ depth was obtained because SOC values in both the continuous corn and soybean-corn systems increased linearly with increasing $\mathrm{N}$ fertilizer rate, while $\mathrm{SOC}$ values in the continuous soybean 


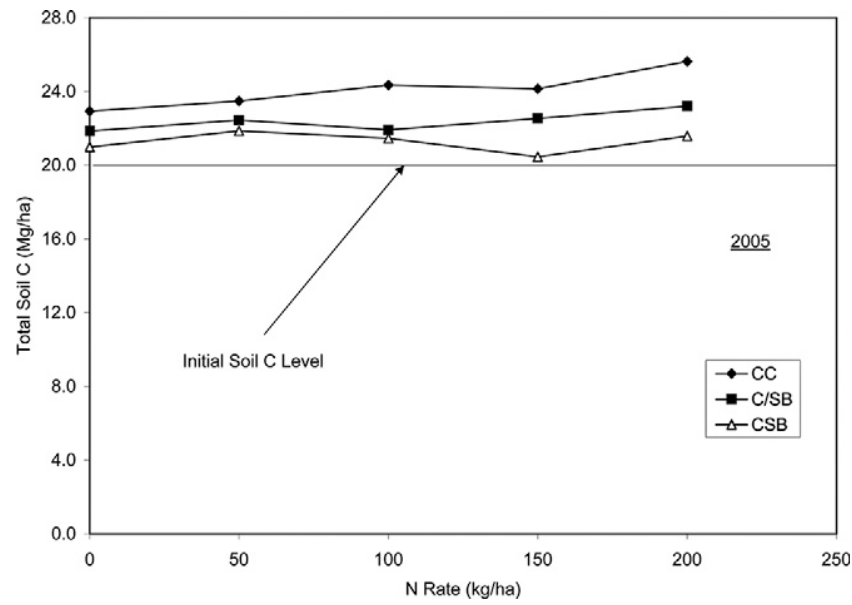

Fig. I. Initial total soil organic carbon (SOC) level (1991) and total SOC levels in the surface $15-\mathrm{cm}$ depth at Shelton, NE, as affected by cropping system and $\mathbf{N}$ fertilizer level in 2005 . CC = continuous corn, CSB = continuous soybean, and 2-yr C/SB = corn-soybean.

system were similar at all $\mathrm{N}$ fertilizer rates. At all the other depths, the significant rotation effect occurred because SOC values were increased in the continuous corn and soybean-corn systems (Table 2 ).

These results provide valuable information that can be used to determine the impact of different residue production levels on SOC values in irrigated high-yield management systems similar to this study (Varvel and Wilhelm, 2003). Changes in SOC levels measured in cropping systems such as these have increased importance with the advancement of proposals and interest in using crop residues for cellulosic ethanol production (Perlack et al., 2005). Perlack et al, (2005) indicated that a significant amount of crop residue is sustainably available for use as biofuel feedstock, but few research data are available to determine the impact of proposed residue removal levels on soils and SOC levels (Wilhelm et al., 2004).

Our results provide data from an irrigated corn production system located in a geographic area where Graham et al. (2007) indicated excess residue would be available for use in cellulosic ethanol production. Total SOC results (0- to $15-\mathrm{cm}$ depth) for samples taken in 2005 from our study are compared in Fig. 1 to those obtained from three composite samples from the entire experimental area in 1991 before initiation of the experiment. This value was calculated by using the average soil organic matter value $(1.7 \%)$ and the average bulk density value for continuous corn from the 2005 sampling. This value was deemed appropriate because before initiation of the study in 1991, the entire field had been in a continuous corn cropping system for over $20 \mathrm{yr}$ with a similar double disk tillage system. Over the duration of our study (1991 to 2005), SOC levels in the 0- to 15-cm depth appear to have remained the same or increased, depending on the management system (Fig. 1). These results were somewhat unexpected, especially in the continuous soybean cropping system. Earlier reports from other locations have shown decreases in SOC levels in continuous soybean cropping systems (Karlen et al., 2006; Varvel, 1994; 2006).

Why have SOC levels either remained at prestudy levels or increased after $14 \mathrm{yr}$ at this location? Since total dry matter samples were collected over the years from both corn and soybean in all cropping systems, we determined the amount

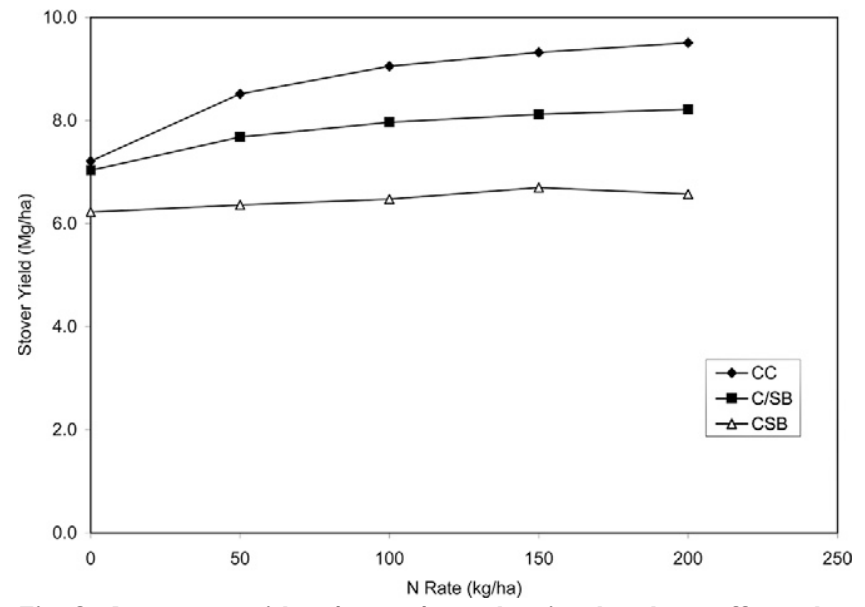

Fig. 2. Average residue (stover) production levels as affected by cropping system and $\mathbf{N}$ fertilizer level at Shelton, $\mathbf{N E}$, over the duration of the study (199I-2004). CC = continuous corn, CSB = continuous soybean, and 2-yr C/SB = corn-soybean.

of aboveground dry matter returned to the soil in each system (Fig. 2). As would be expected, the amount of residue produced (and returned since no stover was removed in this study) was greatest for continuous corn $>$ soybean-corn > continuous soybean cropping systems (Fig. 2). All three cropping systems produced residue amounts equal to or greater than the $6 \mathrm{Mg}$ $\mathrm{ha}^{-1} \mathrm{yr}^{-1}$ of cornstalks cited by Larson et al. (1972) as that amount required to prevent loss of organic matter on a soil in Iowa containing about $1.8 \% \mathrm{C}$. More recently, Johnson et al. (2006), using data from the literature, also estimated that the minimum amount of aboveground source $\mathrm{C}$ inputs to maintain SOC in a moldboard plow tilled system averaged $2.5 \pm 1.0 \mathrm{Mg}$ $\mathrm{C} \mathrm{ha}^{-1} \mathrm{yr}^{-1}$, which equates to approximately $6 \mathrm{Mg} \mathrm{ha}^{-1} \mathrm{yr}^{-1}$ of aboveground residue with an average $C$ content of 42 to $45 \%$.

Our results provide additional data that can be used to evaluate the effects of aboveground residue on SOC levels over an extended period of time in a tilled study. It is evident that greater amounts of residue are produced under irrigation than rainfed conditions in this semiarid environment and at these levels of production, SOC levels have been maintained or increased in certain cropping systems (Fig. 1). It is not clear as to whether increases in SOC such as those obtained in the continuous corn system also equate to significant increases in soil quality and production or whether maintenance of prestudy SOC levels such as what has apparently occurred in the soybean-corn and continuous soybean systems is sufficient for optimum soil quality or productivity. This question can only be answered by examining data from long-term studies such as this one, but even then, the answer may be hard to determine due to the confounding effect of improvement in other aspects of the system (improved hybrids, irrigation management, pest control options, etc.) throughout the duration of the experiment.

Lastly, given the great zeal exhibited in the literature about production of ethanol from crop residues, with the presumption that vast amounts of crop biomass can be removed from the land SUSTAINABLY, it is most critical to state that we observed no change or slightly increased SOC levels in our study when ALL crop residues were returned to the land. The simple equality stated by Follett (2001) that $\Delta \mathrm{SOC}=\mathrm{C}_{\text {input }}-\mathrm{C}_{\text {output }}$ suggests that if inappropriately great amounts of stover are removed, SOC levels will decrease and 
in turn so will soil quality (Shukla et al., 2006). However, we have observed increased stover yields due to $\mathrm{N}$ fertilization over the course of this study (Fig. 2), especially in the continuous corn system. With proper management and appropriate guidelines, it is reasonable to suggest that SOC level can be maintained under these high-yield conditions with modest removal of stover from the land. Key to development of proper management practices and appropriate guidelines are more field studies and in-depth analyses of data as suggested by the Council for Agricultural Science and Technology (2007), Wilhelm (2008), and Johnson (2007).

\section{ACKNOWLEDGMENTS}

This publication is based on work supported by the Agricultural Research Service under the ARS REAP and GRACEnet Projects.

\section{REFERENCES}

Combs, S.M., and M.V. Nathan. 1998. Soil organic matter. p. 53-58. In Recommended chemical soil test procedures for the North Central region. North Central Regional Res. Publ. No. 221 (revised). Missouri Agric. Exp. Stn. SB 1001. Columbia

Council for Agricultural Science and Technology. 2007. Convergence of agriculture and energy: II. Producing cellulosic biomass for biofuels (CAST Commentary). Commentary QTA 2007-x. CAST, Ames, IA.

Follett, R.F. 2001. Soil management concepts and carbon sequestration in cropland soils. Soil Tillage Res. 61:77-92.

Foust, T.D., R. Wooley, J. Sheehan, R. Wallace, K. Ibsen, D. Dayton, M. Himmel, J. Ashworth, R. McCormick, M. Melendez, J.R. Hess, K. Kenney, C. Wright, C. Radtke, R. Perlack, J. Mielenz, M. Wang, S. Synder, and T. Werpy. 2007. A National Laboratory market and technology assessment of the 30x30 scenario. NREL/TP-510-40942, draft publication, March 2007. (Cellulosic Ethanol Production, Section 4, available at http://30x30workshop.biomass.govtools.us/ documents/30x30Section4Only.PDF [accessed 2 July, 2007; verified 2 May 2008]. Dep. of Energy, Washington, DC.

Graham, R.L., R. Nelson, J. Sheehan, R.D. Perlack, and L.L. Wright. 2007. Current and potential U.S. corn stover supplies. Agron. J. 99:1-11.

Johnson, J.M.-F., R.R. Allmaras, and D.C. Reicosky. 2006. Estimating source carbon from crop residues, roots, and rhizodeposits using the national grain-yield database. Agron. J. 98:622-636.
Johnson, J.M.-F., M.D. Coleman, R. Gesch, A. Jaradat, R. Mitchell, D. Reicosky, and W.W. Wilhelm. 2007. Biomass-bioenergy crops in the United States: A changing paradigm. Am. J. Plant Sci. Biotech. 1:1-28.

Karlen, D.K., E.G. Hurley, S.S. Andrews, C.A. Cambardella, D.W. Meek, M.D. Duffy, and A.P. Mallarino. 2006. Crop rotation effects on soil quality at three northern Corn/Soybean Belt locations. Agron. J. 98:484-495.

Lal, R. 2004. Is crop residue a waste? J. Soil Water Conserv. 59:136A-139A.

Larson, W.E., C.E. Clapp, W.H. Pierre, and Y.B. Morachan. 1972. Effects of increasing amounts of organic residues on continuous corn: II. Organic carbon, nitrogen, phosphorus, and sulfur. Agron. J. 64:204-208.

Perlack, R.D., L.L. Wright, A. Turhollow, R.L. Graham, B. Stokes, and D.C. Erbach. 2005. Biomass as a feedstock for a bioenergy and bioproducts industry: The technical feasibility of a billion ton annual supply. Available at http://feedstockreview.ornl.gov/pdf/billion_ton_vision. pdf [verified 9 May 2008]. USDA, Washington, DC.

Ritchie, S.W., J.J. Hanway, and G.O. Benson. 1986. How a corn plant develops. Coop. Ext. Serv. Spec. Rep. 48. Iowa State Univ., Ames.

SAS Institute. 2003. SAS/STAT user's guide. v. 9.1 SAS Inst., Cary, NC.

Schepers, J.S., D.D. Francis, and M.T. Thompson. 1989. Simultaneous determination of total $\mathrm{C}$, total $\mathrm{N}$, and ${ }^{15} \mathrm{~N}$ on soil and plant material. Commun. Soil Sci. Plant Anal. 20:949-959.

Shukla, M.K., R. Lal, and M. Ebinger. 2006. Determining soil quality indicators by factor analysis. Soil Tillage Res. 87:194-204.

Varvel, G.E. 1994. Rotation and nitrogen fertilization effects on changes in soil carbon and nitrogen. Agron. J. 86:319-325.

Varvel, G.E. 2006. Soil organic carbon changes in diversified rotations of the western Corn Belt. Soil Sci. Soc. Am. J. 70:426-433.

Varvel, G.E., J.S. Schepers, and D.D. Francis. 1997. Ability for in-season correction of nitrogen deficiency in corn using chlorophyll meters. Soil Sci. Soc. Am. J. 61:1233-1239.

Varvel, G.E., and W.W. Wilhelm. 2003. Soybean nitrogen contribution to corn and sorghum in two-year cropping systems in the western Corn Belt. Agron. J. 95:1220-1225.

West, T.O., and W.M. Post. 2002. Soil organic carbon sequestration rates by tillage and crop rotation: A global data analysis. Soil Sci. Soc. Am. J. 66:1930-1946.

Wilhelm, W.W., J.M.-F. Johnson, J.L. Hatfield, W.B. Voorhees, and D.R. Linden. 2004. Crop and soil productivity response to corn residue removal: A literature review. Agron. J. 96:1-17.

Wilhelm, W.W., J.M.-F. Johnson, D.L. Karlen, and D. Lightle. 2007. Corn stover to sustain soil organic carbon further constrains biomass supply. Agron. J. 99:1665-1667.

Wilhelm, W.W. 2008. My biomass, your biomass, our solution. Biofpr 2:8-11. 